
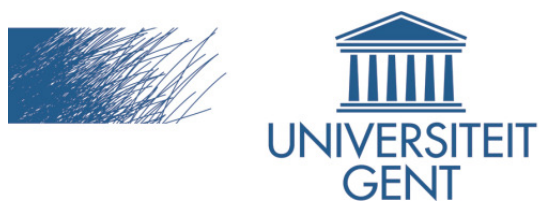

biblio.ugent.be

The UGent Institutional Repository is the electronic archiving and dissemination platform for all UGent research publications. Ghent University has implemented a mandate stipulating that all academic publications of UGent researchers should be deposited and archived in this repository. Except for items where current copyright restrictions apply, these papers are available in Open Access.

This item is the archived peer-reviewed author-version of:

World city networks and global commodity chains: towards a world-system's integration

Brown, E.; Derudder, B.; Parnreiter, C.; Pelupessy, W.; Taylor, P.J.; Witlox, F.

In: Derudder, B.; Witlox, F. (Eds.), Commodity Chains and World Cities, Oxford, WileyBlackwell, p 15-41, 2010.

To refer to or to cite this work, please use the citation to the published version:

Brown, E.; Derudder, B.; Parnreiter, C.; Pelupessy, W.; Taylor, P.J.; Witlox, F. (2010). World city networks and global commodity chains: towards a world-system's integration. In: Derudder, B.; Witlox, F. (Eds.), Commodity Chains and World Cities, Oxford, WileyBlackwell, p 15-41. 


\section{World city networks and global commodity chains: towards a world-systems' integration}

Ed Brown, Ben Derudder, Christof Parnreiter, Wim Pelupessy, Peter J. TAylor, AND FRANK WITLOX

Ed Brown

Department of Geography, Loughborough University, Leicestershire LE11 3TU, UK

e.d.brown@lboro.ac.uk

Ben Derudder

Department of Geography, Ghent University, Krijgslaan 281/S8, 9000 Gent, Belgium ben.derudder@ugent.be

Christof Parnreiter

Department of Geography, University of Hamburg, Bundesstraße 55, D20146 Hamburg Germany

parnreiter@geowiss.uni-hamburg.de

Wim Pelupessy

Development Research Institute (IVO), Tilburg University, Warandelaan 2, 5000 LE

Tilburg, Netherlands

pelupessy@uvt.nl

Peter Taylor

Department of Geography, Loughborough University, Leicestershire LE11 3TU, UK p.j.taylor@1boro.ac.uk

Frank Witlox

Department of Geography, Ghent University, Krijgslaan 281/S8, 9000 Gent, Belgium frank.witlox@ugent.be 
Abstract There are two literatures that explicitly describe spaces of flows that constitute contemporary globalization: world city network analysis and global commodity chain analysis. We explore the possibilities of their integration by returning to their common origins in world-systems analysis. Each model is described and critiqued and it is argued that each can be used to address some of the other's limitations. This is illustrated through world city process additions to understanding the coffee commodity chain and commodity chain additions to understanding Mexico City and Santiago's positioning in the world city network. This complementarity is just a first step towards a more complete integration; the conclusion provides necessary next steps towards just such a research agenda.

Keywords CORE-PERIPHERY, GLOBAL COMMODITY CHAINS, GLOBALIZATION, WORLD CITY NETWORK, WORLD-SYSTEMS ANALYSIS; COFFEE 
The rise of contemporary globalization has generated many new geographies, but spatial patterns and relations have been a neglected theme in the myriad writings on globalization. The purpose of this paper is to address this situation by comparing and contrasting two literatures that focus upon different models of transnational spatial relations: in the world city network (WCN) literature researchers model worldwide inter-city relations; in the global commodity chains (GCC) literature researchers model production processes in the global economy. One of the key properties our selected literatures have in common is that they both depict fundamental spatial models of flows: a chain of production nodes connected by commodity flows and a network of city nodes connected by information flows. However, whilst these literatures share a common world-systems analysis progeny, they have developed independently with little or no cross-referencing. In this paper we take advantage of their shared origin to show how the two models might be integrated and thereby provide a basic spatial skeleton for understanding the processes behind globalization. Because the two literatures already share many of the same conceptual and discursive starting points rather than competing ones, we avoid the dangers of conceptual eclecticism often involved in attempts to bring together different discourses on the same topic.

World-systems analysis is one of the most prominent trans-disciplinary clusters of social scholarship (Wallerstein 2004). As well as being explicitly trans-national, this school of thought encompasses the critical spatiality of the modern world-system as core-periphery structuring of world space through ceaseless capital accumulation; it focuses attention on the spatial dynamics of uneven development. The models we deal with in this paper derive from this fecund source of ideas in different ways. Global commodity chain analysis originates from a concern to show how value is transferred from periphery to core thus sustaining or deepening uneven development. World city network arguments derive from a concern about how global capitalism is concretely commanded and enabled in contemporary globalization. 
Bringing two literatures together is a very large task whatever their degree of synergy. Our argument is divided into two substantive parts. In part one we outline the progress made thus far in mapping trans-state processes and providing analytic models for building new global geographies. This is where we present basic outlines of global commodity chain analysis and world city network analysis. Given the aim of subsequent integration, each description focuses largely upon the fundamental 'space of flows' of each model eschewing much further elaboration to be found in the literatures. For the world city network analysis this means neglecting city networks generated by actors other than advanced producer service firms (for an overview, see Derudder 2006); for global commodity chain analysis it means neglecting more complex structures (i.e. beyond simple chains) to be found in, for instance, global production network (GPN) research (for an overview, see Coe et al. 2008). At this stage of our work it is much more important to identify and consider some of the more fundamental limitations and weaknesses of each basic model and forms of analysis. Our contention is that each model can contribute towards reducing the limitations of the other. In part two we return to the world-systems origins of both models as a route towards their integration. The core-periphery framework is described as providing the spatial structure upon which the world city network and global commodity chain mechanisms operate. In this context we take the first step towards integrating the two models through exploring what each has to offer the other. This is argued both conceptually through connecting their two spaces of flows, and empirically through reviewing evidence from two selected research areas (the coffee commodity chain and world city formation in Mexico City and Santiago de Chile). In a working conclusion we suggest first steps towards more complete integration of global commodity chains with the world city network.

\section{The two literatures: models and analyses}

Both the literatures we employ encompass basic critiques of conventional social science interpretations of their subject matters. We begin each description of the models with these critiques to show how both literatures transcend state-centric thinking and are therefore particularly suited to developing new thinking on globalization. After summary descriptions of each model we consider their limitations and omissions. 


\section{World City Network analysis}

In mainstream urban studies the traditional way of researching inter-city relations has been through analyses of 'national urban systems'. Typically using non-relational data from national censuses, population sizes of cities defined a 'national urban hierarchy'. Models such as 'the law of the primate city' and 'rank size rule' were devised to describe this 'hierarchy' as if the rest of the world did not exist. The study of cities was nationalized, so that city relations were territorialized, to the severe detriment of properly understanding major cities like London and New York. It was only when such cities became interpreted, through a series of influential writings, first as international financial centres (Cohen 1981), then as world cities (Friedmann 1986; Friedmann and Wolff 1982), and further as global cities (Sassen 1991), that a 'world city literature' arose in which the study of cities, or some at least, broke free of national containers. More recently, we have moved from conceptualizations of world city formation to conceptualizations of world city network formation: cities are studied system-wide in the modern world-system as a world city network (Taylor 2004).

The world city network has been specified as an interlocking network in which relations between cities are constituted by intra-firm flows in the advanced producer service sector of the world-economy (Taylor 2001). One of the features of the contemporary world-economy is that 'services' are becoming more and more important. Sassen (1991) pointed out that a key sector of these services, the advanced producer services (such as inter-jurisdictional law and global advertising) used by multinational corporations, were becoming more and more concentrated in leading cities. There were good 'cluster' reasons for such concentration, as the firms operating in these services require information-rich environs to keep ahead in their business. But this need for knowledge did not lead to the concentration of these firms in just one or just a few 'mega service centres'; rather, a second requirement led to these services being offered across the world in cities covering all major regions. This second need of producer service firms was the requirement to provide their service where and when their clients needed it; and since the corporations they serviced were 
becoming global, service firms had no choice but follow suit and go global themselves. The alternative option of farming out their work to partner firms in other cities was never seen as feasible because of the importance of maintaining brand integrity in a field that deals in information and knowledge. Thus major service firms created worldwide office networks across the major cities of the world.

One of Sassen's main arguments is that global cities obtain their overall centrality because they are 'highly concentrated command points in the organization of the world economy' (Sassen 2001: 3). Thus, a key purpose of worldwide office networks is to enable transnational business to be conducted. Projects involving several jurisdictions, languages, cultures, and budgets will draw upon knowledge resources from a range of relevant offices. These intra-firm connections, both electronic and human, flow across the world silently linking the tower blocks that dominate so many cityscapes in all regions of the world. It is the aggregation of all these intra-firm flows - of information, knowledge, instruction, strategy, plans, personnel, etc. - that constitute the contemporary world city network. It is in this sense that advanced producer firms are the 'interlockers' of world cities. Hence when the network is modelled, it is presented as consisting of three layers: the network level at the world-economy scale, the nodal level which is composed of the cities where the work of network formation takes place, and the sub-nodal level which is defined by the firms who are the agents of the whole process. In this interpretation the world city network is a web of 'global service centres', integral parts of complex networks of capital circulation and accumulation. It is important to note that the deliberate sidestepping of national states in this particular specification of the world city network does not imply the suggestion that they do not matter in world city network formation (for in-depth discussions of the multifaceted links between world city-formation and state territorial development under conditions of contemporary globalization, see Brenner 1998 and Olds and Yeung 2004). Rather, it means that such specification should not be a priori shaped by states; the observation that transnational inter-city relations are heavily influenced by national states is viable, but it should be advanced as a result of the analysis rather than being an artefact of its initial specification. 
There are two main limitations of the world city literature; one is commonly voiced whilst the other is becoming increasingly important. The first is the concentration on a relatively few large metropolitan centres to concomitant neglect of all other cities. The most trenchant critique along these lines is by Robinson (2002: 536), who complains that 'millions of people and hundreds of cities are dropped off the map of much research in urban studies'. This exclusion is from two 'maps': (i) the geographical map of world cities wherein most cities in the 'South' are missing; and (ii) the conceptual map of world cities which focuses on a narrow range of global economic processes so that myriad other connections between cities are missing. However, all cities experience contemporary global processes, and globalization can therefore not be construed as affecting just a few privileged cities. Subsequently Robinson (2005: 760) has conceded that the world city literature now covers 'a much wider range of cities around the globe' thus lessening the exclusion from the map. This attempt to broaden our understanding of the world city network has seen the postulation of such ideas as 'globalizing cities' (Marcuse and van Kempen 2000) or 'cities in globalization' (Taylor et al. 2006).

The second main limitation of the world city literature relates to its rather underdeveloped urban-theoretical underpinnings (see, however, Brenner 2004; Hesse this volume; Rozenblat this issue). It can be noted that the dominant arguments in this literature developed from efforts to try and make sense of contemporary economic processes: the two seminal contributions are by Friedmann (1986) figuring out implications of the "new international division of labour', and by Sassen (1991) trying to understand 'the composition of globalization'. Neither Friedmann nor Sassen begins with, or develops, a theory of cities per se. What cities are, and how they relate to one another, are questions that are left unexamined except as a vague hierarchical premise. It is the latter that leads to the privileging of the few. Taylor has argued that this situation can be rectified through a confrontation of the idea of a world city network with the ideas of Jane Jacobs $(1969,1984$, 2000) who treats cities as key economic entities. For Jacobs, vibrant cities expand economic life in ways that diversify economic processes within the city (she calls them 'the little movements') that in turn lead to complex relations with other cities (she calls these the 'big wheels' of commerce). Such a new conceptual context also recognizes Robinson's 
(2005: 757) emphasis on the inherent complexity of cities. Following this line of argument, the use of advanced producer services to define the world city network is not that they encompass most or even a sizeable proportion of the myriad complex flows between cities, rather it is that, as cutting-edge industries, they are critical indicators of vibrancy in Jacobs' sense (Taylor 2006). Today, where there are concentrations of advanced producer services, there is manifest expansion of economic life.

Underlying both limitations and critiques of the world cities literature is the idea that these studies have largely failed to transcend their prime scale of interest, the global. World city studies need to address leading cities in the global economy to be sure, but there is no need to be ghettoized into one-scale analysis. Quite simply, the world city network is built upon ramifications of operations across different scales through macro-regional and national to local (Parnreiter 2003). Although recent attempts to analyse the city network in greater geographical detail (Brown et al. 2002; Derudder et al. 2003; Parnreiter 2002; Rossi and Taylor 2005) have extended our understanding beyond a limited number of leading cities, they fail to explain the connection to other scales. That is, these analyses are the end-result of ever-larger data sets that depart from the logic of considering only the nodes at the global scale, but they are weak at revealing the way in which urban networks at national and regional scales are connected to the wider world city network (but see Hall and Pain 2006). Again, these issues can be addressed by returning to Jacobs (1969) where she describes cities as process; Castells (1996) makes exactly the same point and this has been recently elaborated upon by Taylor et al. (2008, see also Taylor 2006) in their identification of the interlocking model as describing the process of city-ness. In this argument, city-ness is contrasted with the process of 'town-ness'; the latter refers to relations between an urban place and its hinterland - it is essentially local - whereas city-ness includes wider relations and city networks that are non-local. Today's world city network is global. ${ }^{1}$ This networkmaking process can and does occur at different scales and separates contemporary studies of the world city network from earlier primitive 'rosters of world cities' that essentialized the concept. Such work is correctly criticised by Shatkin (2007) but without paying attention to more recent literature. Cities constitute myriad processes in their city-ness; in the twenty-first century large numbers of cities incorporate world city-ness processes 
(advanced producer service provision as described earlier), some more than others. Nowhere, of course, is world city-ness the only process occurring as non-relational essentialist ideas may imply.

\section{Global Commodity Chains}

In mainstream economics the usual way of analysing large-scale commodity flows has been through international trade theories. In general, these theories assert that, in an international economy, economic development emerges from whatever absolute, comparative or competitive advantages a country may have. Many of the theories are based on the neoclassical Heckscher-Ohlin theorem with corresponding restrictive assumptions. The important market clearance condition may be loosened in the chain approach (Busch 2007: 443). Alternative and 'new' trade models tried to reduce some of the limitations by including demand considerations, imperfect competition, scale economics, technologies, dynamic factors and intra industrial trade (Appleyard and Field 1997: 229-62). ${ }^{2}$ However, even without recourse to a refined analysis, it can be noted that the basic assumptions underpinning these (neo-)classical trade theories are fatally flawed by their state-centric spatiality. The underlying supposition that national states are the spatial actors controlling the global economy is indefensible, while the spatiality of trade is of course far more complex than only 'one step'-trade between producers in one country and consumers in another (Díaz 2003: 47-63). For instance, both intra-firm and intra-industry trade constitute an important - and increasing - share of world trade. This makes differentiation an important factor, not only for end products, but also for raw and intermediate materials flows. Furthermore, in the contemporary global economy, production and trade patterns are mostly guided by the strategic behaviour of firms and other economic actors, while (fixed) factor endowments of countries have become less important in explaining commodity flows (Bair 2009). Both industrial organization trends of outsourcing based on new technologies and economic policies of liberalization have made national states clearly insufficient as units of analysis. The overarching analytical disjuncture is that, in spite of the empirical evidence for the importance of trans-state economic flows (as presented in Dicken 2003), conventional theories of economic development have generally been organized around an 
inter-national rather than a trans-national framework. It was only when production and trade became interpreted, via the world-systems writings of Hopkins and Wallerstein in the 1970s (Wallerstein 2009), as a series of cross-border firm-based transactions, that a transnational literature on trade emerged.

Wallerstein and his colleagues hereby introduced the concept of 'commodity chains' as 'a network of labour and production processes whose end result is a finished commodity' (Hopkins and Wallerstein 1986: 159). The emphasis was on the material inputs en route to final consumption, the realization of capital. However, it was only with the advent of the work by Gereffi and Korzeniewicz (1994) that we can speak of a relatively coherent paradigm of 'global commodity chains' focusing on value creation, its distribution and control within transnational networks, which extend in a chain of nodes from raw material exploitation, primary processing, through different stages of trade, services and manufacturing processes to final consumption and waste disposal. Taken as a whole, a global commodity chain may link up different organizational models of production, trade and service providing processes, and can even include the generation of externalities and inter-market spill-overs (Gereffi and Kaplinsky 2001; Pelupessy 2001). The global commodity chain approach is basically an analytical political economy tool, where attention is focused upon the systems of value creation employed by firms and other agents. The connections between these units are conceived of as a chain linking sequences of imperfect markets, reflecting the market power asymmetries that lead to unequal value distributions. The dynamics of any specific chain are determined by the input-output structure of the nodes or chain segments, their geographical location, institutional and socio-political framework and their governance or control structure that gives the commodity chain its hierarchical and unequal character, since '[a] chain without governance would just be a string of market relations' (Humphrey and Schmitz 2001: 20). The importance of the social embeddedness of a chain and eventual state intervention in its markets are hereby considered in the analysis of the socio-political dimension (Pelupessy 2001; Rammohan and Sundaresan 2003). 
There are three main ways in which the global commodity chain approach provides an effective analytical tool for understanding the governance structure of specific chains and their significance. First, there is the asymmetric capacity of participants in the chain to appropriate rents and the barriers to entry of the different nodes. These have a dynamic character, and may be eroded by potential competition (Kaplinsky 2005). Second, there is the behaviour of lead firms involved in the governance structure. This may refer to direct co-ordination of activities on a global scale, the identification and appropriation of dynamic rents, the assignment of specific roles to chain agents, as well as indirect rule setting for the chain. This may open the way for actors from developing countries to upgrade their position in specific global commodity chains (Bair 2009: 29-30). Third, there are the different types of chains defined by the upstream or downstream location of lead firms(s), the kind of dominant or core production factor which they control and others, which are classified as either producer- or demand-driven commodity chains (Gereffi and Korzeniewicz 1994). The importance of the latter category has increased substantially in time and given rise to the concept of demand-responsive economies in for instance East Asia (Hamilton and Gereffi 2009). A recent special issue of Economy and Society (2008) elaborated on the relevance of global chain governance for conceiving the globalization of production and trade. In this context, four aspects are relevant: the historical context, geographic and sectorial unevenenness, specialization, differentiation and changing patterns of ownerships (Gibbon et al. 2000).

Rather than conceptualizing the global economy through a series of exclusively marketoriented containers, the global commodity chain approach allows us to focus on systemwide networks of labour and production processes. As a consequence, this approach is better geared to reveal the spatial ordering of social relations that are being continually reproduced through every day practices of production, distribution and consumption in a globalized economy. Nevertheless, because the focus of the approach is upon the spaces of flows involved in the production of particular commodities, commodity chain research has been less successful in specifying how chains contribute towards the complex dynamics of the broader economic system in which they are located (Bair 2003). 
Some would go further in this critique. Coe et al. (2004) and Smith et al. (2002) argue that, despite the global focus of the commodity chain approach, it still remains preoccupied with the nation-state as geographical scale of analysis. They back this up through reference to Gereffi's (1999) paper on the prospects for 'industrial upgrading' which he defines as 'improving the position of firms or nations in international trade networks' (1999: 39). The result, Coe et al. (2004) and Smith et al. (2002) argue, is that global commodity chain analysis 'has surprisingly little to say about regional and subnational processes, because of the focus on the international dimensions of commodity chains and global divisions of labour' (Smith et al. 2002: 49). However, recent Latin American empirical studies gave more attention to local and subnational impacts of global chains (Díaz 2003: 172-93; a conceptual framework on integrating vertical and horizontal analysis of value chains is given by Bolwig et al. 2008).

Global commodity chain research also lacks a comprehensive treatment of the spatiality of commodity chains (Leslie and Reimer 1999). Despite the theoretical insight that a global commodity chain connects inputs from different parts of the world, pulls them together in specific sites and provides output to different locations, the study of the actual geographies of these commodity chains has remained relatively underdeveloped. Although a number of writings have focused on the role of global commodity chains in regional development and the potentials of localities (e.g. Schmitz 2000, and some contributions in the volume edited by Hughes and Reimer 2004), an overarching spatial conceptualization remains an unfulfilled task. That is, there is a critical need to trace commodity chains spatially, as place-bound linkages between different localities.

Another more specific limitation in global commodity chain research is that the empirical scope of analysis has been somewhat limited, with the majority of studies focusing on a number of primary commodities and industrial sectors. Services, in particular, despite an early call for exploring the 'service sector nexus' (Rabach and Kim 1994), have not been analyzed particularly effectively in commodity chain research, either in industries where the service constitutes a commodity in its own right or where it is used to facilitate the production of other more tangible commodities (for an interesting recent effort to overcome 
these deficiencies, see Li Yang and Yu (2007)). ${ }^{3}$ However, it is perhaps above all the lack of attention that has been paid to understanding the crucial role of producer services in setting up and sustaining global networks of production that has been the most crucial omission in this literature (Daniels and Bryson 2002).

\section{World-Systems integration}

The main contention of this paper is that the route to integrating world city network with global commodity chains is through emphasizing their common world-systems origins. But before we proceed it must be noted that their relations to the development of world-systems analysis are quite different. For instance, whereas in early Political economy of the WorldSystem series volumes, Number XVI on commodity chains could reproduce pioneer papers by Wallerstein and Hopkins, the founders of the world-systems approach (Gereffi and Korzeniewicz 1994), these authors are absent from Number XIV on 'Cities in the WorldSystem' (Karaba 1991). In fact there has been a debate about the neglect of cities in worldsystems analysis (Smith 2003). Wallerstein's (1984) only paper on 'cities' is actually about urbanization; a process that he has subsequently renamed 'de-ruralification'. Thus, despite early important studies within this school of thought (e.g. Chase-Dunn 1983; King 1990; Timberlake 1985) cities have not been central to world-systems research in general and Wallerstein's writings in particular in the way that commodity chains have. Perhaps the most city-centred theoretical contribution to the research that presents itself as 'worldsystems analysis' is the work of Arrighi (1994 2007). In particular Arrighi's 1994 work The long twentieth century, in which he reinterprets the history of capitalism since the thirteenth century as a series of alternations between 'material expansions' and 'financial expansions', is relevant in this context. Although in many ways intellectually close to Immanuel Wallerstein, in this work Arrighi tends to focus less on spatial divisions of labour and more on the anchoring transnational material/financial networks across space. Although his main objective is not to understand cities per se, his focus on the territorial interlocking of the different flows leads him to considering the relevance of the fourteenth century Italian citystates for the emergence of global capitalism, and after the consolidation of the inter-state 
system on cities such as Antwerp, Seville and Lyons in their role central market places for the trans-statal activities of foreign business organizations (Arrighi 1994: 128).

This means that although core-periphery distinctions are central to global commodity chain analysis, allusions to links between the world city network and core-periphery are limited to their apparent (if not commonsensical) coincidence. The real linkages remain obscure and are passed over in silence. For instance, in the seminal paper that was one of the world cities literature's original texts, Friedmann (1986) explicitly invokes world-systems analysis in his hierarchical classification of cities through including a division between cities in 'core countries' and cities in 'semi-peripheral countries'. But the world-systems analysis Friedmann calls upon remains at this basic conceptual level; there is nothing on how cities are implicated in the creation of core-periphery structures through commodity chains. Cities are described as 'control and command centres' through their housing of multinational corporate headquarters, but how this translates into the operation of, and control over, commodity chains is not broached. Saey (1996: 122) is the most severe critic in this respect arguing that the apparent spatial correlation between world city-formation and core processes is in and by itself insufficient to speak of a systematic relation between both structures. As a consequence, it can be noted that the title of Knox and Taylor's World cities in a world-system (1995) reflects an ambition rather than a reality.

However, as pointed out in the previous section, Taylor $(2004,2006)$ has recently brought back world-systems thinking into the study of world cities by using Jane Jacobs' categories of economically dynamic and stagnant cities, albeit again without reference to commodity chains themselves. It is Parnreiter (2003, et al. 2007) who has addressed the problematic absence of conceptual linkages between both approaches in an analysis of world city formation in Mexico City and Santiago de Chile, and it is this work that is discussed later in this section.

\section{Core-periphery structure}


In contrast to our argument here, Dicken et al (2001: 99-100) have explicitly complained about the 'world-systems ancestry' of commodity chain analysis with its core-periphery framework, and Leslie and Reimer (1999: 404) have objected to the 'highly dualistic language' that leads to a 'surface level' geography. Many core-periphery models that abound in the social sciences can be justly criticized for their simplistic dualism but this is not the case with world-systems analysis. Hence the criticisms above are based upon a misunderstanding of the subtleties of the core and periphery concepts in world-systems analysis. Rather than 'surface' outcomes, core-periphery in world-systems analysis is a deep structure from which both global commodity chain formation and world city network formation derive and whose mechanisms shape both types of spaces of flows. The key point about core and periphery in world-systems analysis is that they are not unchanging geographical categories, rather they are the spatial structures underpinning a very dynamic world-economy. ${ }^{4}$

At the simplest level, core and periphery can be seen as bundles of systemic mechanisms that create contrary outcomes. Core processes are associated with historically high wage, high-tech, high profit inputs and outcomes (e.g. the work of lead firms in managing commodity chains is an example of a core mechanism), peripheral processes are associated with the opposite. Geographically, these processes have tended to concentrate and segregate (reflecting the evolution of market power, entry barriers and forms of chain governance). This produces places where core processes dominate and where peripheral processes dominate. For short-hand purposes these may be designated as 'core' and 'periphery' but they must never be seen as purely one or the other: so-called 'core countries' encompass numerous, if minority, peripheral processes; and the opposite is so for 'peripheral countries'. 5 Thus Wallerstein's (1979, 2004) conceptualization, far from producing a simple 'dual world', suggests a most complex geography of interweaving contrary processes based upon a quite sophisticated social model. Importantly, in some places the contrary processes are approximately balanced - the concentration/segregation has not transpired - and with no dominant processes, the outcome is referred to as semiperiphery. 
The important point here is that the core-periphery model is central to both global commodity chain and world city network analysis. As regards global commodity chain analysis, a major reason for using the model is to trace chains across the core-periphery boundary to expose the inequities of the geographies of how value is added and profit taken within the chain. In the case of world city network analysis delineating core/semiperiphery/periphery by state jurisdictions has been replaced by city-based delimitations. For instance, the core is defined as locales where core processes dominate: the cities and cityregions of the three 'globalization arenas' - northern America, Pacific Asia and Western Europe and peripheralization can be equated with Jacobs (1984) description of the pernicious effects of dynamic cities on vulnerable locales beyond their city-region in an extension of Frank's (1969) dependency thesis. Obviously this revision of core-periphery model takes the interweaving of the two processes to a more complicated geography than the usual definitions employing states as the constituents of the spatial categories (e.g. Arrighi and Drangel 1986; Terlouw 1992). This interpretation replaces the weak use of world-systems terminology in Friedmann (1986) where 'core " cities are designated because they are located in 'core countries'.

What are the implications of this for integrating global commodity flows with the world city network? First, basically all global commodity flows in the world-economy include core-formation processes, and that is why the chain cannot be initiated and sustained without world cities, wherever they may be located. These processes are needed to exercise control over commodity chains. Commodity flow branches bring value in from cities at all nodes and this leads to further consequent flows of profits to cities. This idea can be traced back to Sassen's original argument that world cities (or, in her terms, 'global cities') are centres for both the management and the command of the world economy. Although Sassen does not use the global commodity chain terminology, her notion that a city's capacity to export producer services points to the capabilities for servicing and controlling global operations of firms exactly suggests what is elaborated here: world cities form critical nodes in numberless commodity chains, because it is from these cities that core inputs required by all production chains are provided. It is in this sense that Sassen provides although only analysing three major cities in considerable depth - an account that is 
valuable to understand the structure of the world economy at large. Second, all cities are integrated into commodity chains, and that is how they are connected to the world city network, even if their own input into the chain is only of peripheral character. Thus, it is

only from being within such spaces of flows that cities can be sustained within the worldeconomy. Global commodity chains and the world city network are therefore integral to the spatiality that is the core-periphery structure of the capitalist world-economy.

\section{World City Network process in Global Commodity Chains}

A world city can be seen as a critical node within commodity chains, precisely for its insertion of advanced services into the production process. Thus, every world city is a service node in and for a myriad of chains, thereby obtaining its overall centrality. Our argument is that it is service intermediaries, the so-called producer services, located in world cities that maintain the connections between the networks of world cities and commodity chains. The innovation here is the assertion that service intermediaries, which provide the connectivity within urban networks, are also of particular significance for the efficient functioning of global commodity chains because they offer key inputs (see also Jacobs et al. this issue; Lüthi et al. this issue). From a bank's initial lending of capital to initiate production, to the use of an advertising agency's services to facilitate final consumption, the provision of producer services through cities is essential in linking dispersed production and consumption sites and, therefore, to the successful operation of commodity chains. We illustrate this for the coffee global commodity chain.

The coffee commodity chain constitutes a traditional primary commodity with long established systems of supply and demand across the globe, and is also currently an arena of rapid change including major price movements, significant readjustments in the distribution of income amongst the various participants within the chain (as the industry has been still further globalized) and major transformations in both how the final product is marketed and where (Daviron and Ponte 2005; Talbot 2004). A number of studies have attempted to apply a commodity chain (or value chain) analysis to the sector (Daviron and Ponte 2005; Fitter and Kaplinsky 2001; Pelupessy 1999; Talbot 2004). Their findings 
illustrate the economic polarization in the sector. On the one hand, despite the massive role that supermarkets play within the retail of coffee, the roasting companies have managed to maintain strong control of the coffee commodity chain. This has been achieved particularly through massive investment in advertising, bonus systems to maintain brand loyalty, blending and other non-price competition instruments (Pelupessy and Díaz 2008). On the other hand, austerity reforms via structural adjustment have robbed small growers of access to credit and state-sponsored marketing and extension services. As such, now 'producers sell only atomistically into commodity markets. These atomistic producers lack the capacity to combine forces' (Fitter and Kaplinsky 2001: 72 It is this more than anything that lies behind the regular crises facing coffee producing areas.

Nevertheless, for all the strengths of commodity chain analysis, there is little or no recognition of the critical role of finance in the various stages of the production cycle (how it is obtained, managed and safe-guarded at different points along the chain) and the changing relationship between the major players in the sector and the financial markets in the liberalized world of the past couple of decades (particularly in the expanded complexity and reach of trading in futures). There is also no explicit place for advertising agencies except as inputs to either roasting or trading activities. To an extent, this is because of the way in which commodity chain analysis has tended to treat services as separate chains within which knowledge is the commodity traded (Clancy 1998; Rabach and Kim 1994). However to do so in the case of producer services has the effect of isolating the analysis of individual commodity chains such as coffee from the necessary service providers who enable the development and reproduction of the chain (see Vind and Fold, this issue). Furthermore, it is worth reiterating that these are producer services and, as such, their knowledge commodity is not an end product in itself. Producer service knowledge commodities feed into other commodity chains that do lead to a final realization of capital (the concentration of financial rents by producer service providers and their relationship with other lead firms in the chain is a topic worthy of further detailed discussion).

The four major roasting companies are major global corporations and their myriad engagements within globalization are exceedingly complex. This global complexity is 
managed through headquarter and other governance levels as part of the command and control functions of world cities. These are the 'decision' cities through which advanced producer services are contracted (Rossi et al. 2007). These services are carried out in 'service' cities where the professional, creative and financial work takes place. It is this work that, to a large extent, makes possible the operation of the coffee commodity chains. A company like Nestlé will support its coffee commodity chains using: banking/financial corporations, both local and global, in order to fund expansions; both insurance and law firms will be engaged for all projects that entail any risk; accountants and management consultants will be used to audit accounts and enhance profit margins to grow shareholder dividend; advertising agencies are crucial to marketing both nationally and globally. Thus, every stage in the commodity chain will involve professional, creative or financial inputs from cities; often chains will run through local cities (near production nodes), at other times through major cities distant from production nodes (for example the use of major advertising agencies in New York or major insurance corporations in London). Clearly, in order to function in an increasingly complex and globalizing world economy, commodity chains have to disseminate through city networks. ${ }^{6}$ Figure 1 summarizes this suggested cross-fertilization by showing how cities play a crucial role in commodity chains through their dual function of servicing producers and final consumption.

Figure 1: Model integration - one commodity chain and two world cities. 


\section{THE WORLD CITY NETWORK IN GLOBAL \\ COMMODITY CHAINS}

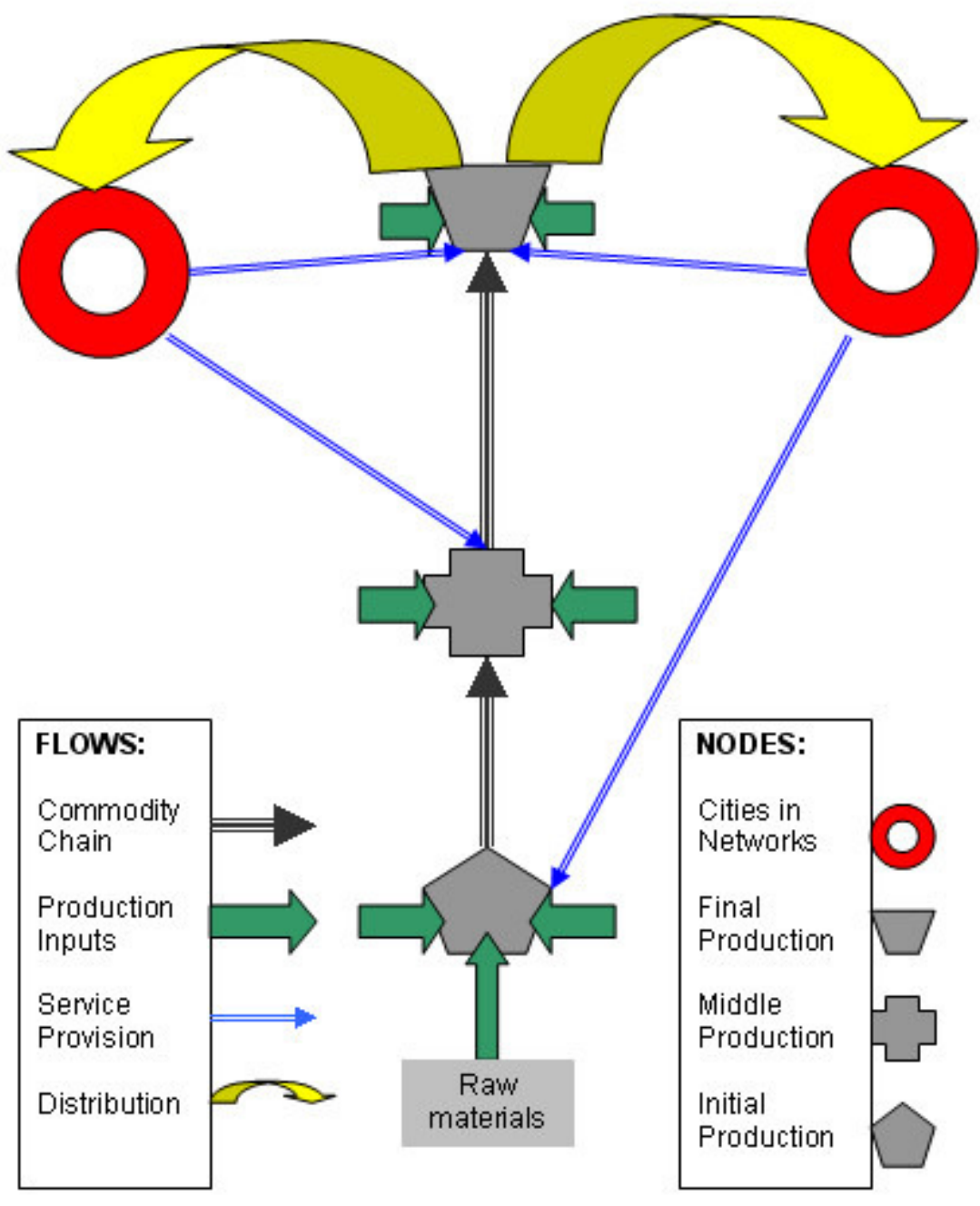

\section{Global Commodity Chain process in World City Network formation}

Through modelling commodity chains we can draw attention to inter-city relations beyond the leading world cities, since these commodity chains reveal how many smaller settlements are connected to the world city network through the various flows of capital, labour, goods, services, etc. Global commodity chains do explicitly include the stages of primary production, which are located in rural areas and related to city-based transformation and trade processes (Jacobs 1969). Such an examination may thus help to develop a more spatially refined analysis of the world city network, depicting also the 
specific roles of those cities seemingly at the margins of the world city network. In order to do this, the data on the location strategies of individual companies may be extended with information on the geography of their clients (thus grasping backward and forward linkages). To this end, we need data on the geographic location of the clients of advanced producer firms (see Rossi et al. 2007). In particular, we need analysis of service provision through cities as a process that directly contributes to commodity chains; Parnreiter et al. (2007) have carried out just such a study of a specific financial process in Mexico City and Santiago (for a more detailed analysis of the Mexico City case, see Parnreiter, this issue).

This research starts from the identification of the 'missing link' between two findings: Mexico and Chile are increasingly integrated in a variety of global commodity chains, and globally organized advanced producer services are highly centralized in Mexico City and in Santiago. It remained an assumption, however, that advanced producer services in both cities are essential in articulating production in the two countries with the world market. If world city-ness is to be understood as a process (i.e. providing advanced services for making global production feasible), then the multifaceted links between firms whose economic activities are geared towards the world market and service providers in a specific city have to be revealed.

Parnreiter et al. (2007) set out to explore one of those links through a study of the involvement of (local and global) financial institutions in issuing of bonds and shares of leading corporations in Mexico and Chile, starting from the assumption that the provision of this kind of financial service represents an important input for the functioning of a commodity chain. The study shows that between 1982 and 2004 most of the bond and share issues of the 50 top ranked Mexican and Chilean enterprises were handled by global financial institutions such as Citibank/Citigroup, JP Morgan/Chase Manhattan, Bank of New York, Banco Santander or ING Bank. More importantly, however, it was shown that the big corporations in Mexico and in Chile prefer those global financial institutions that maintain offices in Mexico City and/or Santiago de Chile. Demand for financial service intermediaries is, therefore, concentrated in firms operating both at a global and a local scale. As a result, the locational strategies of banks and other financial institutions can best 
summarized through the 'glocalization' concept (Swyngedouw 1997) or, in the words of UBS: 'We operate in two locations: Everywhere, and right next to you.' Two New York banks with local offices are particularly important: Citibank/Citigroup services four of the Top 10 firms in Mexico and two of the Top 10 in Chile, while JP Morgan/Chase Manhattan provides financial services to three of the Top 10 firms in Mexico and to four of the Top 10 in Chile.

Parnreiter et al. (2007) attribute this preference for 'glocal' financial institutions to several factors. First, leading companies in Mexico and Chile seek out banks with sufficient global experience in order to place bond and share issues at major financial markets (in this case New York, Luxembourg, Frankfurt). Second, it is reasonable to assume that the Mexican branch of a transnational company chooses a bank already involved in stock market transactions of the headquarter in, say, the United States. Third, the importance of a local office lies in so-called 'soft' factors, such as the initiation of business deals, an in-depth analysis of the company that sets out to issue bonds or shares, preparation of the "pitch material' (information on financial position, investment strategies, profile of costumers, production description, etc.).

It is in this way that commodity chains instituted by leading corporations in Mexico and Chile are contributing towards Mexico City and Santiago's positioning in the world city network. For instance, Citibank/Citigroup generate high value work in both cities through providing key inputs for several global commodity chains: by enabling investment for the Mexican oil company PEMEX or the Chilean copper company Codelco through bonds and shares at stock markets; by selling financial services to major retailers (e.g. Wal-mart Mexico, Controlada Comercial Mexicana) creating new commodity chains. Citibank/Citigroup acts therefore as an inter-locker in the world city network in their facilitation of myriad commodity chains. By playing a crucial role in both networks, 'glocalized' financial institutions provide the indispensable connection between the world city network and global commodity chains: all global commodity chains 'run' through world cities, and all cities are integrated into commodity chains. Figure 2 summarizes this suggested cross-fertilization by showing how the operation of commodity chains is 
facilitated by myriad service provisions from cities. An office in one city might, for instance, service a production node in its hinterland (e.g. a city financing the beginning of one chain and providing the advertising for the other chain), while on other occasions expertise from more than one office is used to service a producer (e.g. the advertising for the right hand chain is more complex and brings in expertise from offices in both cities); similarly the latter chain requires a multi-office legal services (inter-jurisdictional) whereas the left hand chain uses a law firm from its local city for a uni-jurisdictional legal requirement.

Figure 2: Model integration - one world city network dyad and two commodity chains.

\section{GLOBAL COMMODITY CHAINS IN THE WORLD} CITY NETWORK

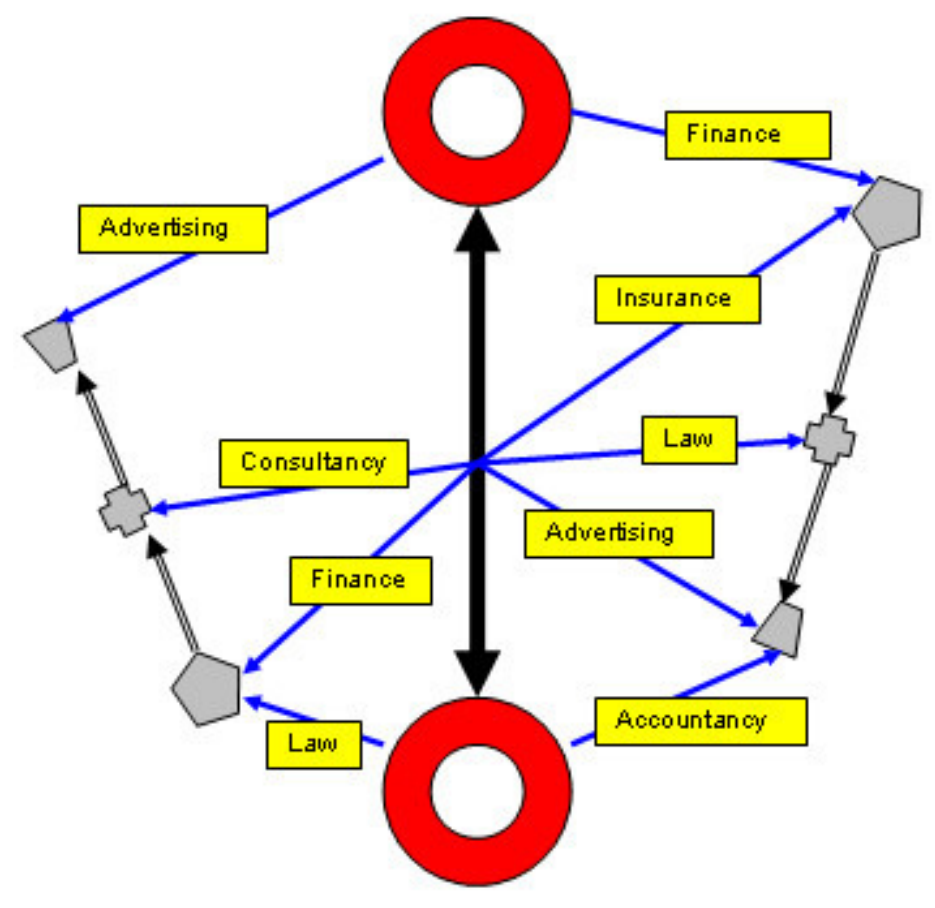

Inter-city link formed by joint servicing projects 
There are, however, important differences between the spatialities of commodity chains and the world city network as well as between specific commodity chains (e.g. primary production, manufacturing, services). On the whole, these differences stem from the degree of core-ness of the processes that constitute the flows sustaining the respective chain or network. While the world city network is by definition formed exclusively through the flows of high valued and highly monopolized activities, commodity chains are maintained by a multitude of flows. Although some of them are associated with core processes, many others are based on low-wage activities of producers which are easy to substitute.

There are three inter-related spatialities to this difference. First, the prevalence of world cities differs markedly across the networks in question. Though commodity chains (like the coffee chain analyzed above) necessarily run through world cities, these represent only a minor fraction of all nodes in the chain, while the prevailing localities in commodity chains are those cities and villages which tend to be 'off the world cities map' (Robinson 2002: 536). Second, there is a difference in the frequency and density of the connectivity to the 'global'. While world cities are linked to each other through multiple, extensive and constant flows, many localities are connected only through the flow of one or two item. The result is a (very) different degree of centrality within global networks. Third, the world city network is geographically much more horizontal structured than commodity chains. Though the flows connecting Mexico City to other world cities are surely not even, there is no clear-cut hierarchy between the financial institution in New York and its regional office in Mexico City (Parnreiter et al. 2007). Conversely, all research on governance in commodity chains reveals that these are hierarchical and unequal in character.

\section{Conclusion: what might an integrated research agenda look like?}

Our ultimate goal is to produce a synthesis of world city network analysis and global commodity chain analysis and this paper is intended as a first step towards that objective. We have argued that both analytic frameworks have things to learn from each other and this can be a springboard to possible, eventual integration. 
The first task is to create dense empirical evidence on how producer service firms in world cities interact with firms in commodity chains. The challenge consists in really documenting these flows of information, capital, etc. in at least two ways. Forward-linkages of producer service firms and the (service) backward-linkages of firms in commodity chains must be mapped in order to grasp (a) the geographical reach of operations which emanate in world cities but which in many cases will go beyond the world city network; and (b) the spatial stretching of global commodity chains towards specific world cities inputting producer services. In addition, the characteristics of the flows between producer service firms in world cities and firms in commodity chains have to be to assessed as regarding the core-ness of the processes involved (e.g. as value creation, possibility to and the grade of monopolization).

Second, this new knowledge has to be fed back into the conceptualization of the two types of spaces of flows in order to overcome the limitations of each model. As regards world city network formation, to identify the manifold linkages between world and non-world cities across different scales will help to understand how global cities relate to globalizing cities. Another expected result is a refined analysis of world city network formation itself. Mapping the geographical scales of service provision in a specific city, and detailing information on the core-ness (or not) of these inputs will lead to a comprehensive understanding of how big this city's wheels are (to use Jacobs words) in making global production feasible. As to global commodity chains, the full integration of services into their analysis and the related goal to treat the spatiality of the chain comprehensively are not ends in themselves. Rather, both efforts might lead to a more detailed understanding of where(from) control over production is exercised and how and where value is created and appropriated.

The cross-fertilization of the two models suggested represents the first step to their integration. If the integration proposed proceeds and eventually succeeds, world cities and global commodity chains will no longer be treated separately. The creation and (unequal) distribution of value along commodity chains is organized in and governed from world cities, while - vice versa - the capacity to create the means of control of value creation and 
distribution and the power to deploy them is the underlying force in world city formation. This reciprocal relationship is because core-formation processes are necessary for and hence inherent to both the organization of commodity chains and the formation of world cities.

\section{Notes}

1 Of course, external urban relations are a little more complicated than this: 'local' is itself variable as when hinterlands are arranged into central place hierarchies. The key point is whether the urban process is inward-looking - centred on place (town-ness) - or outwardlooking - centred on flows (city-ness). For further discussion see Taylor et al. (2008).

2 For comparisons of the basic underlying assumptions of these models see Díaz (2003: 51, $56,59)$.

3 Chain studies on tourism are also available (Clancy 1998; IFC 2006; Yilmaz and Bititci 2006).

4 In our reading, this critique of a 'surface level' geography in which 'core' is being equated with 'core states' misconceives Wallerstein's basic ideas. Admittedly, Wallerstein never elaborated what 'core' meant in geographical terms. However, in his writings, he uses the neutral term 'zones' when referring to core/periphery geographies, which may or may not be states. For instance, in the first volume of The modern world-system, Wallerstein (1974) points to the fact that northern France is 'in' the core while Mediterranean France is 'in' the semi-periphery. Many later writers use 'core' and 'core state' as synonyms for empirical rather than conceptual reasons (e.g. Arrighi and Drangel 1986; Terlouw 1992).

5 Even the most 'core' of all 'core zones' (i.e. the consecutive hegemons of the worldsystem) encompass peripheral processes. For instance, at the height of its hegemony, the UK included a very typical peripheral process in a major way (the Irish famine); similarly at the height of US hegemony the 'South', a major division of the state, remained resolutely 'uncore-like' in both its economics and politics.

6 In addition to this extant complexity, the markets are themselves highly dynamic, creating new threats and opportunities that the roasting companies have to respond to with the help of their global service providers. Moreover, it is the commercial milieu of the cities of the 
world city network itself where the consumption styles of urban consumers are created and recreated. The shifts in consumers' preferences towards non-material or symbolic attributes of goods are introduced and developed in urban areas, and frequently these are related to growing income levels. This suggests that there are more points of contact between commodity chain and world city network approaches: by recognizing the increasing consumer orientation of especially buyer-driven global chains, cities play an essential role in shaping consumers preferences, fashions and habits, which ascertain the flows of information along the chains; this again brings into the analysis consideration of the role of advertising and other producer services in creating and adapting new markets for coffee. Considerable internal changes to the governance of the coffee chain have been occasioned by new entrants into the retail market such as Starbucks and their competitors. These new firms have themselves made considerable use of professional and creative services. It is in major cities that these cutting edge marketing initiatives transforming traditional commodity chains are being developed and diffused. Thus, the neat circular argument for

services beginning in cities at all stages of the chain and capital in the chain being realized through new retailing innovations in cities.

\section{Acknowledgements}

We would like to thank the editor and two anonymous referees for their extensive and insightful comments, which have certainly helped sharpening the line of argumentation in this paper. This paper draws on an earlier and broader elaboration of the argument, which can be downloaded as a GaWC Research Bulletin from http://www.lboro.ac.uk/gawc/.

\section{References}

Appleyard, D. and A. Field (1997) International economics, New York: Richard D. Irwin Inc.

Arrighi, G. (1994) The long twentieth century: money, power and the origins of our times, New York: Verso. 
Arrighi, G. (2007) Adam Smith in Beijing: lineages of the twenty-first century, New York: Verso.

Arrighi, G. and J. Drangel (1986) 'The stratification of the world-economy: an exploration of the semiperipheral zone,' Review, X(1), 9-74.

Bair, J, (2003) 'From commodity chains to value chains and back again?', paper presented at 'Rethinking Marxism', University of Massachusetts at Amherst, available on-line at http://www.csiss.org/events/meetings/time-mapping/files/bair_paper.pdf last accessed 18 August 2008.

Bair, J. (2009) 'Global Commodity Chains: genealogy and review' in: J., Bair (ed.) Frontiers of commodity chain research, Stanford: Stanford University Press, 1-34.

Bolwig, S., L. Riisgaard, S. Ponte, A. du Toit and N. Halberg (2009) 'Integrating poverty and environmental concerns in to value chain analysis. A conceptual framework,' DIIS Working Paper, 2008/16.

Busch, L. (2007) 'Performing the economy, performing science: from neoclassical to supply chain models in the agrifood sector,' Economy and Society, 36, 437-466.

Brenner, N. (1998) 'Global cities, glocal states: global city formation and state territorial restructuring in contemporary Europe,' Review of International Political Economy, 5(1), 137.

Brenner, N. (2004) New state spaces: urban governance and the rescaling of statehood, Oxford: Oxford University Press.

Brown, E., G. Catalano, and P. J. Taylor (2002) 'Beyond world cities: Central America in a space of flows,' Area, 34, 139-48.

Castells, M. (1996) The rise of the network society, Oxford: Blackwell.

Chase-Dunn, C. (1983) 'Urbanization in the world-system: new directions for research,' Comparative Urban Research, 9, 41-46.

Clancy, M. (1998) 'Commodity chains, services and development: theory and preliminary evidence from the tourism industry,' Review of International Political Economy, 5, 122 148.

Coe, N., M. Hess, H.W-C. Yeung, P. Dicken, and J. Henderson (2004) 'Globalizing regional development: a global production networks perspective,' Transactions of the Institute of British Geographers, 29(4), 468-484. 
Coe, N., P. Dicken, and M. Hess (2008) 'Global production networks: realizing the potential,' Journal of Economic Geography, 8(3), 271-295.

Cohen, R. (1981) 'The new international division of labour, multinational corporations, and urban hierarchy,' in M. Dear and A. Scott (eds) Urbanization and urban planning in capitalist society, Methuen: London, 287-315.

Daniels, P. and J. Bryson (2002) 'Manufacturing Services and Servicing Manufacturing: changing forms of production in advanced capitalist economies,' Urban Studies, 39(5-6), 977-91.

Daviron B. and S. Ponte (2005) The coffee paradox, global markets, commodity trade and the elusive promise of development, London \& New York: Zed Books.

Derudder, B. (2006) 'On conceptual confusion in empirical analyses of a transnational urban network,' Urban Studies, 43(11), 2027-46.

Derudder, B., P. J. Taylor, F. Witlox, and G. Catalano (2003) 'Hierarchical tendencies and regional patterns in the world city network: a global urban analysis of 234 cities,' Regional Studies, 37(9), 875-86.

Díaz, R. (2003) 'A developing country perspective on policies for sustainable agribusiness chains: The case of Costa Rica,' NICCOS, 43.

Dicken, P. (2003) Global shift: reshaping the global economic map in the 21 st century $\left(4^{\text {th }}\right.$ edition), London: Sage Publications.

Dicken, P., P. Kelly, K. Olds and H. W-C. Yeung (2001) 'Chains and networks, territories and scales. Towards a relational framework for analysing the global economy,' Global Networks, 1, 99-123.

Fitter, R. and R. Kaplinsky (2001) 'Who gains from product rents as the coffee market becomes more differentiated? a value chain analysis,' IDS Bulletin, 32, 69-82.

Frank, A. (1969) Latin America: underdevelopment or revolution?, New York: Monthly Review Press.

Friedmann, J. (1986) 'The world city hypothesis,' Development and Change, 17, 69-83.

Friedmann, J. and G. Wolff (1992) 'World city-formation: an agenda for research and action,' International Journal of Urban and Regional Research, 6, 309-44.

Gereffi, G. (1999) 'International trade and industrial upgrading in the apparel commodity chain,' Journal of International Economics, 48, 37-70. 
Gereffi, G. and M. Korzeniewicz (eds) (1994) Commodity chains and global capitalism, Westport: Praeger.

Gereffi, G. and R. Kaplinsky (eds) (2001) 'The value of value chains: spreading the gains from globalization,' IDS Bulletin, 32(3).

Gibbon, P., J. Bair, and S. Ponte (2008) 'Governing global value chains: an introduction,' Economy and Society, 37, 315-38.

Hall, P. and K. Pain (eds) (2006) The polycentric metropolis: learning from mega-city regions in Europe, Earthscan: London.

Hamilton, G. and G. Gereffi (2009) 'Global commodity chains, market makers and the rise of demand-responsive economies' in J. Bair (ed.) Frontiers of commodity chain research, Stanford: Stanford University Press. 136-162.

Hopkins, T. and I. Wallerstein (1986) 'Commodity chains in the world-economy prior to 1800,' Review, 10(1), 157-70.

Humphrey, J. and H. Schmitz (2001) 'Governance in global value chains,' IDS Bulletin 32(3), 19-23.

Hughes, A. and S. Reimer (eds) (2004) Geographies of commodity chains, Routledge: London.

IFC (International Finance Corporation) (2006) 'The tourism sector in Mozambique: A value chain analysis' (Vol. I and II), IFC: Washington, D.C.

Jacobs, J. (1969) The economy of cities, Vintage: New York.

Jacobs, J. (1984) Cities and the wealth of nations, Random House: New York.

Jacobs, J. (2000) The nature of economics, Vintage: New York.

Kaplinsky, R. (2005) Globalization, poverty and inequality: between a rock and a hard place, Cambridge: Polity Press.

Karaba, R. (1991) Cities in the world-system, Westport: Greenwood Press.

King, A. (1990) Global cities, Routledge: London.

Knox, P. and P. J. Taylor (eds) (1995) World cities in a world-system, Cambridge:

Cambridge University Press.

Leslie, D. and S. Reimer (1999) 'Spatializing commodity chains,' Progress in Human

Geography, 23(3), 401-20. 
Li Yang, C. and M. Yu (2007) 'The impact of producer services on manufacturing value chain,' International Journal of Services Operations and Informatics, 2 (4), 421-38.

Marcuse, P. and R. Van Kempen (eds) (2000) Globalizing cities, Blackwell: Oxford.

Olds, K. and H. Yeung (2004) 'Pathways to global city formation: a view from the developmental city-state of Singapore,' Review of International Political Economy, 11(3), 489-521.

Parnreiter, C. (2002) 'Mexico: the making of a global city?' in S. Sassen (ed.) Global networks, linked cities, London: Routledge, 145-82.

Parnreiter, C. (2003) 'Global city formation in Latin America: socioeconomic and spatial transformations in Mexico City and Santiago de Chile,' paper presented at the 99th Annual Meeting of the Association of American Geographers, New Orleans, 4-8 March also GaWC Research Bulletin Nr. 103, available on-line at http://www.lboro.ac.uk/gawc/rb/rb103.html, accessed 18 August 2008.

Parnreiter, C., K. Fischer, and K. Imhof (2007). 'El enlace faltante entre cadenas globales de producción y ciudades globales: el servicio financiero en Ciudad de México y Santiago de Chile,' Eure, 33, 100, 135-48.

Pelupessy, W. (1999) 'Coffee in Côte d'Ivoire and Costa Rica: national and global aspects of competitiveness,' in H. Van der Laan, T. Dijkstra and A. van Tilburg (eds) Agricultural marketing in tropical Africa, Aldershot: Ashgate, 109-130.

Pelupessy, W. (2001) 'Industrialization in global commodity chains emanating from Latin America,' UNISA Latin American Report 17(2), 4-14.

Pelupessy, W. and R. Diaz (2008) 'Upgrading of lowland coffee in Central America,' Agribusiness: An International Journal, 24(1), 119-40.

Ponte, S. (2002) 'The "late revolution"? regulation, markets and consumption in the global coffee chain,' World Development, 30(7), 1099-1122.

Rabach, E. and E. Kim (1994) 'Where is the chain in commodity chains? the service sector nexus,' in G. Gereffi and M. Korzeniewicz (eds) Commodity chains and global capitalism, Westport: Praeger, 123-143.

Rammohan, K. and R. Sundaresan (2003) 'Socially embedding the commodity chain: An exercise in relation to coir yarn spinning in Southern India,' World Development, 31(5), 903-23. 
Robinson, J. (2002) 'Global and world cities: a view from off the map,' International Journal of Urban and Regional Research, 26(3), 531-54.

Robinson, J. (2005) 'Urban geography: world cities, or a world of cities,' Progress in Human Geography, 29, 757-65.

Rossi, E. and Taylor, P. (2005) 'Banking networks across Brazilian cities: interlocking cities within and beyond Brazil,' Cities, 22(5), 381-93.

Rossi, E., J. Beaverstock, and P. J. Taylor (2007) 'Transaction links through cities: 'decision cities' and 'service cities' in outsourcing by leading Brazilian firms,' Geoforum, $38(4), 628-42$.

Saey, P. (1996) 'Het wereldstedennetwerk: de nieuwe Hanze?', Vlaams Marxistisch Tijdschrift, 30(1), 120-23.

Sassen, S. (1991) The global city, Princeton: Princeton University Press.

Sassen, S. (2001) The global city, $2^{\text {nd }}$ edition, Princeton: Princeton University Press.

Schmitz, H. (2000) 'Global competition and local cooperation: success and failure in the Sinos Valley, Brazil,' World Development, 27, 1627-50.

Shatkin, G. (2007) 'Global cities of the South: Emerging perspectives on growth and inequality,' Cities, 24(1), 1-15.

Smith, A., A. Rainnie M. Dunford, J. Hardy, R. Hudson, and D. Sadler (2002) 'Networks of value, commodities and regions: reworking divisions of labour in macro-regional economies,' Progress in Human Geography, 26, 41-63.

Smith, D. (2003) 'Rediscovering cities and urbanization in the $21^{\text {st }}$ century world-system,' in W. Dunaway (ed.) Emerging issues in the $21^{\text {st }}$ century world-system, vol. II, Westport: Praeger, 111-29.

Talbot, J. (2004) Grounds for agreement: the political economy of the coffee commodity chain, Rowman \& Littlefield Publishers: New York.

Taylor, P. J. (2001) 'Specification of the World City network,' Geographical Analysis, 33, 181-194.

Taylor, P. J. (2004) World city network: a global urban analysis, London: Routledge.

Taylor, P. J. (2005) 'World-systems analysis and globalization: a Jacobsean exploration of pasts, presents and futures,' Belgeo, 3, 265-73. 
Taylor, P. J. (2006) 'Cities within spaces of flows: theses for a materialist understanding of the external relations of cities,' in P. Taylor, B. Derudder, P. Saey and F. Witlox (eds) Cities in globalization, Routledge: London, 287-97.

Taylor, P. J., B. Derudder, P. Saey, and F. Witlox (eds) (2006) Cities in globalization, London: Routledge.

Taylor, P. J., M. Hoyler, and R. Verbruggen (2008) 'External urban relational process: introducing central flow theory to complement central place theory,' GaWC Research Bulletin 261, http://www.lboro.ac.uk/gawc/rb/rb261.html, accessed 8 August 2008.

Terlouw, C. (1992) The regional geography of the world-system: external arena, periphery, semiperiphery, core, Utrecht: Faculteit Ruimtelijke Wetenschappen Universiteit Utrecht.

Timberlake, M. (ed.) (1985) Urbanization in the world-economy, New York: Academic Press.

Wallerstein, I. (1974) The modern world-system I: capitalist agriculture and the origins of the European world-economy in the sixteenth century, New York, Academic Press.

Wallerstein, I. (1979) The capitalist world-economy, Cambridge: Cambridge University Press.

Wallerstein, I. (1984) 'Cities in socialist theory and capitalist praxis,' International Journal of Urban and Regional Research, 8, 64-72.

Wallerstein, I. (2004) World-systems analysis, Durham, NC: Duke University Press.

Wallerstein, I. (2009) 'Protection networks and commodity chains in the capitalist worldeconomy' in J. Bair (ed.) Frontiers of commodity chain research, Stanford: Stanford University Press. 83-90.

Yilmaz, Y. and U. Bititci (2006) 'Performance measurement in tourism: A value chain model,' International Journal of Contemporary Hospitality Management, 18, 341-49. 